\title{
JUKMAS
}

\section{Prediksi Pengaruh Implementasi Kegiatan Pemberantasan Sarang Nyamuk (PSN) Terhadap Kejadian DBD}

\author{
Meithyra Melviana Simatupang ${ }^{1}$, Ely Yuliah ${ }^{2}$ \\ ${ }^{1}$ Fakultas IImu Kesehatan, Program Studi Kesehatan Masyarakat, Universitas Respati Indonesia \\ ${ }^{2}$ Unit Kesehatan Lingkungan Rumah Sakit Umum Daerah Ciracas \\ Email : meithyra@urindo.ac.id
}

\begin{abstract}
Abstrak
Pemberantasan Sarang Nyamuk (PSN) di lingkungan masyarakat menjadi fokus utama pencegahan dan pengendalian penyakit demam berdarah dengue (DBD). Program dilaksanakan melalui praktik menghilangkan tempat perkembangbiakan dan menghindari gigitan nyamuk. Penelitian ini bertujuan untuk mengetahui pengaruh praktik PSN terhadap kejadian DBD. Studi case control ini dilaksanakan di wilayah Kerja Puskesmas Kecamatan Ciracas Jakarta Timur dengan melakukan wawancara kepada sampel dari kelompok kasus dan kontrol, masing-masing berjumlah 47 orang. Sampel kelompok kasus merupakan penderita DBD yang tercatat di rekam medis Puskesmas Ciracas pada bulan Januari-April 2020. Sedangkan sampel kelompok kontrol merupakan tetangga terdekat sampel kasus dengan karakteristik kelompok usia, jenis kelamin dan lingkungan rumah yang sama. Meskipun demikian, responden penelitian yang akan diwawancarai untuk mengumpulkan data harus berusia minimal 15 tahun untuk menghindari bias informasi. Korelasi positif dengan kejadian DBD dibuktikan berdasarkan analisis bivariat pada variabel menguras bak mandi, menutup tempat penampungan air, mengelola barang yang tidak dipakai, menggunakan penghalau nyamuk, dan memelihara ikan pemakan jentik. Di antara faktor-faktor tersebut, uji regresi logistik menunjukkan bahwa kegiatan menguras bak mandi secara rutin seminggu sekali memiliki pengaruh paling besar terhadap kejadian DBD. Namun, menutup tempat penampungan air dikeluarkan dari pemodelan analisis multivariat karena menunjukkan nilai probabilitas yang tidak bermakna. Berdasarkan hasil tersebut, dapat diprediksi bahwa responden yang tidak menguras bak mandi, tidak menggunakan penghalau nyamuk, tidak memelihara ikan pemakan jentik, dan tidak mengelola barang yang tidak dipakai akan menderita DBD.
\end{abstract}

Kata kunci: menguras, anti nyamuk, ikan, kelola sampah, DBD

\begin{abstract}
Eradication of Mosquito Nests (PSN) in community environment is the prior focus of dengue hemorrhagic fever (DHF) prevention and control, implemented through the practice of eliminating breeding sites and avoiding mosquito bites. The aimed of the study was to determine the most influence of PSN practice against the incidents of DHF. The case control study arranged at Puskesmas Kecamatan Ciracas Jakarta Timur work area, then interviewed sample from case and control group, as many as 47 people from each group. Samples of case group were DHF patients who registered at medical record of Puskesmas Ciracas in JanuaryApril 2020. While samples from control group were the closest neighborhood of every case sample with similiar characteristic by age group, sex, and house environment. Nevertheless, research respondent which will be interviewed to collect data had to more than 15 years old to prevent information bias. Positive correlation against DHF incidents proved by bivariat analysis
\end{abstract}

http://ejournal.urindo.ac.id/index.php/jukmas

Article History :

Submitted 30 Desember 2020, Accepted 28 April 2021, Published 30 April 2021 
of draining water container, using container lid, unused stuff management, using repellent, and keeping larvivorous fish. Among of those factors, logistic regression test showed regularly drained water container once a week had the most effect to DHF incident. At the same time, used of container lid had no significance value, so that was being expelled from model of multivariate analysis. Based on this result, it can be predicted that respondent who not drained water container, not used repellent, not kept larva-eating fish, and not manage unused stuff will suffer DHF.

Keywords : drained container, repellent, larvivorous fish, manage unused stuff, DHF

\section{PENDAHULUAN}

Virus dengue merupakan agent penyebab penyakit Demam Berdarah Dengue (DBD). Tipe virus DEN - 1, DEN - 2, DEN - 3 dan DEN-4 merupakan tipe yang paling umum ditemukan di Indonesia.[1] Penderita DBD umumnya mengalami demam $2-7$ hari disertai pendarahan, penurunan jumlah trombosit $<100.000 / \mathrm{mm}^{3}$, adanya kebocoran plasma, dan peningkatan hematokrit $\geq 20 \%$ dari nilai normal.[2] Gejala lain yang dapat muncul berupa sakit kepala, nyeri pada mata, otot dan persendian.[3]

Penularan DBD dari orang yang terinfeksi ke orang yang sehat dapat terjadi melalui gigitan nyamuk Aedes, yang merupakan vektor utama dari penyakit ini Nyamuk jenis ini umum terdapat di Indonesia, kecuali di daerah dengan ketinggian lebih dari $1.000 \mathrm{mdpl} .[1]$

Pola hidup (bionomik) vektor dapat menjadi dasar sebagai upaya pencegahan dan pengendalian penyakit melalui vektor. Dengan mengetahui perilaku perindukan, pola mencari makan, tempat istirahat, dan mobilitas nyamuk Aedes, disusun program pencegahan dan pengendalian demam berdarah berupa program
Pemberantasan Sarang Nyamuk (PSN). Kegiatan utama dari program PSN atau 3M plus berupa menguras, menutup, dan mengubur/mengelola wadah-wadah penampungan air di sekitar rumah yang dapat menjadi tempat yang disukai nyamuk Aedes untuk meletakkan telurnya (biasa disebut $3 \mathrm{M}$ ), serta beberapa kegiatan tambahan seperti menaburkan larvasida, memelihara ikan pemakan jentik di wadah air, menanam tanaman pengusir nyamuk, memakai anti nyamuk, menggunakan kelambu, dan memasang kawat kasa pada ventilasi rumah. Kegiatan-kegiatan tersebut bertujuan untuk mengurangi populasi nyamuk di sekitar pemukiman masyarakat.

Berdasarkan pencatatan Dinas Kesehatan Provinsi DKI Jakarta, kasus DBD di tahun 2018 berjumlah 3.007 kasus, tahun 2019 sebanyak 8.765 kasus, dan pada bulan Januari - April tahun 2020 tercatat sebanyak 2.256 kasus.[4] Wilayah dengan incidence rate yang cukup tinggi di DKI Jakarta yaitu Jakarta Timur khususnya di Kecamatan Ciracas, dengan laporan 350 kasus DBD pada tahun 2019 dan 47 kasus pada periode Januari sampai April 2020.

Studi ini dilaksanakan untuk melihat gambaran mengenai kegiatan PSN yang dilaksanakan 
masyarakat di Kecamatan Ciracas, sekaligus mencari tahu pengaruhnya terhadap kejadian DBD, dan menemukan faktor yang paling berpengaruh untuk dapat dijadikan dasar program pencegahan dan pengendalian DBD di Kecamatan Ciracas, atau di wilayah lain dengan karakteristik lingkungan dan masyarakat yang sama.

\section{METODE}

Penelitian ini menggunakan pendekatan analitik dengan desain studi case control. Penelitian dilaksanakan pada bulan Juni - Juli 2020. Populasi studi merupakan seluruh masyarakat yang tinggal di Kecamatan Ciracas dengan sampel penelitian untuk kelompok kasus yaitu semua pasien DBD yang tercatat di rekam medis Puskesmas Kecamatan Ciracas pada bulan Januari - April 2020 berjumlah 47 orang (total sampling). Untuk kelompok kontrol, ditetapkan jumlah yang sama yaitu 47 orang dengan beberapa kriteria seperti persamaan jenis kelamin, kelompok umur (rentang 5), dan karakteristik lingkungan rumah, dengan jarak maksimal dari rumah sampel kasus sejauh 100 meter (purposive sampling). Dengan demikian, keseluruhan responden pada penelitian ini berjumlah 94 orang.

Pengumpulan data mengenai kegiatan pemberantasan sarang nyamuk (PSN) dilakukan dengan mewawancarai responden dengan kuesioner sebagai instrumen penelitian. Untuk menghindari bias informasi, jika sampel (kelompok kasus dan kontrol) berusia kurang dari 15 tahun, maka yang menjadi responden adalah penghuni rumah yang berusia lebih dari
15 tahun dan berada di rumah saat pengumpulan data. Sampel pada kelompok kasus yang sedang sakit, sudah meninggal, tidak lagi bertempat tinggal di wilayah kerja Puskesmas Kecamatan Ciracas, dan tidak bisa ditemui sebanyak tiga kali selama masa pengumpulan data ditetapkan sebagai kriteria eksklusi.

Pengumpulan data untuk studi ini dilakukan bertepatan dengan pandemi COVID-19. Oleh karena itu, pengumpulan data dilakukan dengan mempraktikkan protokol kesehatan, seperti penggunaan masker dan menjaga jarak, yang dipatuhi oleh pewawancara dan responden penelitian. Wawancara dilaksanakan dengan persetujuan dari responden. Tidak ada konflik kepentingan dalam pelaksanaan studi ini. Studi ini sudah mendapat ethical clearance dari Lembaga Penelitian dan Pengabdian Masyarakat (LPPM) Universitas Respati Indonesia berdasarkan Surat Keterangan Nomor 043/SK.KEPK/UNR/VI/2020 sebelum pelaksanaan penelitian dilakukan.

\section{HASIL DAN PEMBAHASAN}

Keseluruhan responden yang menjadi sampel penelitian dapat ditemui ketika pengumpulan data. Berdasarkan data, ditemukan bahwa mayoritas penderita DBD berjenis kelamin perempuan (66\%) dan berusia $\geq 15$ tahun (55\%). Sebagian sampel dari kelompok kasus berumur kurang dari 15 tahun. Untuk menghindari bias informasi, dengan mempertimbangkan beberapa variabel penelitian mungkin kurang dipahami oleh responden berusia $<15$ tahun, wawancara akan dilakukan kepada penghuni rumah yang 
berusia lebih dari 15 tahun dan berada di rumah pada saat pengumpulan data. Sampel untuk kelompok kontrol merupakan tetangga terdekat dari kelompok kasus yang dipilih berdasarkan kriteria jenis kelamin, kelompok umur, serta kondisi lingkungan yang sama dengan kelompok kasus. Untuk sampel kontrol yang berusia kurang dari 15 tahun, responden yang diwawancara juga digantikan dengan orang yang lebih tua. Karakteristik responden pada studi ini dirangkum pada Tabel 1.

Tabel 1. Analisis Karakteristik Responden Penelitian

\begin{tabular}{|c|c|c|}
\hline & Kasus & Kontrol \\
\hline & $n=47$ & $n=47$ \\
\hline \multicolumn{3}{|l|}{ Jenis Kelamin } \\
\hline Laki-laki & $16(34,0 \%)$ & $21(44,7 \%)$ \\
\hline Perempuan & $31(66,0 \%)$ & $26(55,3 \%)$ \\
\hline \multicolumn{3}{|c|}{ Kelompok Umur (tahun) } \\
\hline Mean & 32,21 & 33,51 \\
\hline St. deviasi & 11,65 & 9,76 \\
\hline $15-19$ & $6(12,8)$ & 0 \\
\hline $20-24$ & $11(23,4)$ & $9(19,1)$ \\
\hline $25-29$ & $6(12,8)$ & $10(21,3)$ \\
\hline $30-34$ & $4(8,5)$ & $9(19,1)$ \\
\hline $35-39$ & $5(10,6)$ & $7(14,9)$ \\
\hline $40-44$ & $4(8,5)$ & $5(10,6)$ \\
\hline $45-49$ & $6(12,8)$ & $3(6,5)$ \\
\hline $50-54$ & $5(10,6)$ & $4(8,5)$ \\
\hline \multicolumn{3}{|l|}{ Pendidikan } \\
\hline SD & $1(2,1 \%)$ & $0(0)$ \\
\hline SMP & $8(17,0 \%)$ & $2(4,3 \%)$ \\
\hline SMA & $27(57,5)$ & $37(78,7 \%)$ \\
\hline PT & $11(23,4)$ & $8(17,0 \%)$ \\
\hline
\end{tabular}

Sumber: Data Primer, 2020

Tabel 1 menunjukkan bahwa mayoritas responden untuk kedua kelompok studi berjenis kelamin perempuan. Rata-rata umur dan pendidikan responden juga tidak jauh berbeda. Kriteria responden tidak menjadi variabel dalam penelitian ini karena merupakan variabel yang digeneralisasikan pada kelompok kasus dan kontrol untuk menemukan perbandingan yang sesuai.

Data yang dikumpulkan terkait tindakan PSN responden dalam penelitian ini mencakup rutin menguras wadah untuk menampung air di kamar mandi setidaknya seminggu sekali, menutup wadah penampung air bersih di sekitar lingkungan rumah, mengelola barang tidak dipakai yang merupakan tempat perindukan nyamuk di sekitar rumah, menaburkan larvasida di wadah penampung air yang sulit dikuras secara berkala, memelihara ikan pemakan jentik (seperti ikan kepala timah, ikan gupi, dan ikan cupang) di wadah penampung air, menanam tanaman pengusir nyamuk di sekitar rumah, menggunakan penghalau nyamuk (dalam bentuk lotion, anti nyamuk bakar, anti nyamuk elektrik, atau anti nyamuk semprot), menggunakan kelambu untuk menghindari gigitan nyamuk di jam 08.00-10.00 dan 16.00-18.00, dan memasang kawat kasa pada ventilasi rumah. Sebagian besar responden sudah melaksanakan kegiatan-kegiatan PSN tersebut sebagai upaya mencegah penyakit DBD. Namun, terdapat pula sebagian responden, dari kelompok kasus dan kontrol, yang belum melaksanakan PSN atau 
Jurnal Untuk Masyarakat Sehat (JUKMAS)

tidak rutin melakukannya. Hasil analisis tindakan

PSN responden terdapat pada Tabel 2.

Tabel 2. Hubungan Tindakan Terhadap Kejadian DBD

\begin{tabular}{|c|c|c|c|c|c|c|}
\hline \multirow{3}{*}{ PSN } & \multicolumn{4}{|c|}{ Kejadian DBD } & \multirow[b]{3}{*}{ p. } & \multirow[b]{3}{*}{ OR } \\
\hline & \multicolumn{2}{|c|}{ Kasus } & \multicolumn{2}{|c|}{ Kontrol } & & \\
\hline & $\mathbf{N}$ & $\%$ & $\mathbf{n}$ & $\%$ & & \\
\hline \multicolumn{7}{|c|}{ Menguras bak mandi } \\
\hline Tidak & 1 & 2,1 & 8 & $\begin{array}{r}17, \\
0\end{array}$ & $0,030^{\mathrm{a}}$ & $\begin{array}{c}9,43 \\
6\end{array}$ \\
\hline Ya & 46 & $\begin{array}{r}97 \\
9\end{array}$ & 3 & $\begin{array}{r}83 \\
0\end{array}$ & & \\
\hline
\end{tabular}

\section{Menutup penampungan air}

Tidak 10

21, $242,0,046$

2,74

30

1

Ya

78, 257 ,

37

$$
\begin{array}{lll}
7 & 7 & 4
\end{array}
$$

Mengelola barang tidak dipakai

Tidak

$$
12
$$$$
25, \quad 248, \quad 0,033^{b} \quad 2,79
$$$$
539
$$

Ya

$\begin{array}{rrr}74, & 2 & 51, \\ 5 & 4 & 1\end{array}$

\section{Memelihara ikan pemakan jentik}

Tidak 15

$31,257, \quad 0,022 \quad 2,88$

$9 \quad 7^{4} \quad 4^{b}$

0

Ya

32

$$
\text { 68, } 242 \text {, }
$$$$
106
$$

Menggunakan penghalau nyamuk

$\begin{array}{rrrrrrr}\text { Tidak } & & 12, & 1 & 31, & 0,048^{\mathrm{b}} & 3,20 \\ & 6 & 8 & 5 & 9 & 3 \\ \text { Ya } & & 87, & 3 & 68, & \\ & 41 & 2 & 2 & 1 & \end{array}$

\begin{tabular}{|c|c|c|c|c|c|c|}
\hline \multirow{3}{*}{ PSN } & \multicolumn{4}{|c|}{ Kejadian DBD } & \multirow[b]{3}{*}{$p$. } & \multirow[b]{3}{*}{ OR } \\
\hline & \multicolumn{2}{|c|}{ Kasus } & \multicolumn{2}{|c|}{ Kontrol } & & \\
\hline & $\mathbf{N}$ & $\%$ & $\mathbf{n}$ & $\%$ & & \\
\hline \multirow{3}{*}{ Ya } & \multirow{3}{*}{29} & 3 & 2 & 8 & & \\
\hline & & 61, & 2 & 53 & & \\
\hline & & 7 & 5 & 2 & & \\
\hline \multicolumn{7}{|c|}{ Menaburkan larvasida } \\
\hline \multirow[t]{2}{*}{ Tidak } & \multirow{2}{*}{19} & 40 & 1 & 23 & $0,121^{b}$ & \\
\hline & & 4 & 1 & 4 & & \\
\hline \multirow[t]{2}{*}{ Ya } & \multirow{2}{*}{28} & 59 & 3 & 76 & & \\
\hline & & 6 & 6 & 6 & & \\
\hline
\end{tabular}

Menanam tanaman pengusir nyamuk

Tidak 18 38, $246,0,531^{\text {b }}$

\begin{tabular}{lrrrrr}
\multicolumn{5}{l}{ Menggunakan kelambu } \\
Tidak & & 63, & 3 & 68, & $0,828^{\text {b }}$ \\
& 30 & 8 & 2 & 1 & \\
& & 36, & 1 & 31, & \\
Ya & 17 & 2 & 5 & 9
\end{tabular}

Memasang kawat kasa di ventilasi

Tidak 13 $27,123,0,813^{b}$

Ya 34

$\begin{array}{lll}7 & 1 & 4\end{array}$

72, 376 , 366

Keterangan uji statistik: ${ }^{\mathrm{a}}$ Fisher Exact, ${ }^{\mathrm{b}}$ Chi-square Sumber: Data Primer, 2020

Analisis bivariat membuktikan adanya pengaruh antara variabel menguras bak mandi, menutup penampungan air, mengelola barang tidak dipakai, memelihara ikan pemakan jentik, dan menggunakan penghalau nyamuk dengan keajadian DBD $(p .<0,05)$. Berdasarkan perhitungan nilai OR (odds ratio), risiko kejadian DBD kira-kira 3 kali lebih tinggi pada partisipan yang tidak melaksanakan kegiatan-kegiatan PSN tersebut. Bahkan, risikonya 9,4 kali lebih besar 


\section{Jurnal Untuk Masyarakat Sehat (JUKMAS)}

jika menguras bak mandi tidak rutin dilaksanakan.

Analisis multivariat menggunakan uji regression logistic merupakan uji lanjutan dengan mengikutsertakan variabel penelitian yang bermakna secara statistik, yaitu variabel menguras bak mandi, menutup penampungan air, mengelola barang tidak dipakai, memelihara ikan pemakan jentik, dan menggunakan penghalau nyamuk. Tujuannya, untuk mengetahui variabel bebas yang mempunyai pengaruh paling besar terhadap kasus DBD.

Pemodelan terakhir pada analisis regresi logistik menunjukkan bahwa terdapat empat variabel yang bermakna secara statistik, yaitu menguras bak mandi, mengelola barang yang tidak dipakai, memelihara ikan pemakan jentik, dan menggunakan penghalau nyamuk. Variabel menutup wadah penampung air dikeluarkan pada pemodelan sebelumnya karena hasil analisis menunjukkan nilai p.>0,05. Hasil uji multivariat disajikan pada Tabel 3.

Tabel 3. Hasil Analisis Multivariat

\begin{tabular}{lccccc}
\hline \multicolumn{1}{c}{ Variabel } & B & p. & OR & & \multicolumn{2}{c}{$\mathbf{9 5 \%} \mathbf{C l}$} \\
\cline { 5 - 6 } & & & & Lower & Upper \\
\hline Menguras bak & & & & & \\
mandi & 2,556 & 0,024 & $\mathbf{1 2 , 8 8}$ & 1,40 & 118,52 \\
\hline Mengelola & & & & & \\
barang tidak & 1,188 & 0,017 & 3,28 & 1,23 & 8,73 \\
dipakai & & & & & \\
\end{tabular}

Memelihara

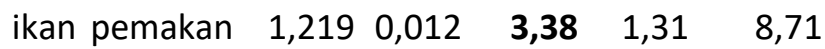
jentik

\begin{tabular}{llllll}
\hline Menggunakan & 1,258 & 0,035 & $\mathbf{3 , 5 2}$ & 1,09 & 11,33
\end{tabular} penghalau

nyamuk

Constant 10,995

Sumber: Data Primer, 2020

Regresi logistik juga menganalisis ketepatan pemodelan akhir studi ini. Hasilnya dapat terlampir pada Tabel 4.

\section{Classification Table ${ }^{a}$}

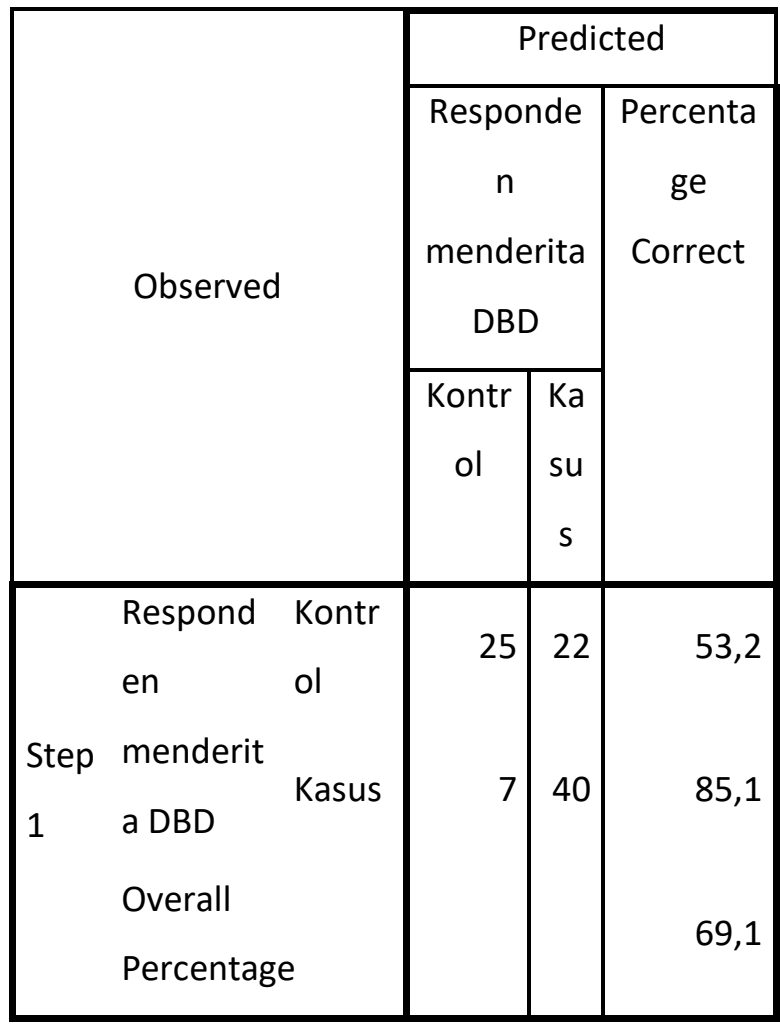

a. The cut value is, 500

\section{Tabel 4. Classification Table}

Sumber: Data Primer, 2020

Classification table pada Tabel 4 menunjukkan nilai overall percentage sebesar $(25+40) / 97=$ $69,1 \%$. Artinya, ketepatan model penelitian ini yaitu sebesar $69,1 \%$. 
Faktor yang paling berpengaruh terhadap kejadian DBD ditentukan oleh nilai tertinggi koefisien regresi $(B)$ dan $\operatorname{Exp}(B)$ sebagai nilai OR pada tabel 3. Kekuatan hubungan terbesar sampai ke yang terkecil pada variabel-variabel tersebut yaitu variabel menguras bak mandi $(\mathrm{OR}=12,88)$, menggunakan penghalau nyamuk $(\mathrm{OR}=3,52)$, memelihara ikan pemakan jentik $(\mathrm{OR}=3,38)$, dan mengelola barang yang tidak dipakai $(O R=3,28)$.

Analisis multivariat menemukan 4 faktor utama yang berasosiasi dengan kejadian DBD, yaitu menguras bak mandi, menggunakan penghalau nyamuk, memelihara ikan pemakan jentik, dan mengelola barang yang tidak dipakai. Prediksi kejadian DBD dengan persamaan regresi $\mathrm{Y}=$ $10,995+2,556$ (menguras bak mandi) $+1,258$ (menggunakan penghalau nyamuk) $+1,219$ (memelihara ikan pemakan jentik) $+1,188$ (mengelola barang yang tidak dipakai).

Persamaan regresi $Y$

$=\ln \frac{P}{1-P}$ jentik, dan pengelolaan barang yang tidak dipakai tidak dilaksanakan, maka diprediksi akan menderita DBD.

\section{Menguras Bak Mandi}

Uji statistik pada penelitian ini membuktikan adanya korelasi positif antara kegiatan menguras wadah penampungan air di kamar mandi dengan kejadian DBD. Variabel ini bahkan merupakan faktor yang memiliki pengaruh paling besar berdasarkan analisis multivariat.

Hasil yang sama diperoleh Novrita dkk, yang menemukan tidak menguras tempat penampungan air menimbulkan risiko kejadian DBD 3,67 kali lebih besar.[5] Ayun dkk bahkan menemukan bahwa tidak memiliki kebiasaan menguras wadah penampung air berisiko 8 kali lebih tinggi.[6]

Penelitian kasus kontrol di Pekanbaru menunjukkan bahwa demam berdarah berisiko 2,94 kali lebih besar pada responden yang menguras bak mandi lebih dari seminggu sekali.[7]

$$
=\frac{(\exp (-10,995)+(2,556 \times 1)+(1,258 \times 1)+(1,219 \times 1)+(1,188 \times 1)}{(1+(\exp (-10,995)+(2,556 \times 1)+(1,258 \times 1)+(1,219 \times 1)+(1,188 \times 1)}
$$

$$
\begin{aligned}
& =\frac{6,219}{7,219} \\
& =0,862
\end{aligned}
$$

Berdasarkan perhitungan probabilitas di atas $0,862>0,5$. Sehingga, dapat diinterpretasikan jika kegiatan menguras bak mandi, penggunaan penghalau nyamuk, memelihara ikan pemakan
Sebuah studi pada 350 rumah tangga di daerah perkotaan dan pedesaan di Thailand menemukan frekuensi membersihkan wadah penampungan air di rumah lebih dari 1 minggu sampai sebulan sekali memiliki asosiasi yang lebih besar terhadap keberadaan jentik nyamuk di kontainer-kontainer tersebut, dibandingkan 
dengan responden yang membersihkan kontainer seminggu sekali. [8]

Air di tempat penampungan harus dikuras secara keseluruhan. Membuang dan mengganti air yang sudah kotor, namun tidak menyikat wadah air memungkinkan telur nyamuk yang tertinggal dan menempel pada dinding kontainer. Telur yang tertinggal berpotensi untuk dapat berkembang menjadi nyamuk dewasa.[9]

Berdasarkan siklus hidupnya, nyamuk memerlukan waktu sekitar 7-14 hari untuk berkembang dari telur menjadi nyamuk dewasa.[7] Meskipun waktu yang diperlukan bisa berubah tergantung pada kondisi lingkungan, kondisi ini cukup untuk menjadi dasar dari rutinitas menguras atau membersihkan tempat penampungan air sebaiknya dilakukan minimal seminggu sekali. Tujuannya untuk menghambat siklus hidup nyamuk dengan mengeliminasi telur dan jentik nyamuk sehingga nyamuk tidak sempat berkembang biak di kontainer air. Adanya tempat perindukan nyamuk Aedes mengindikasikan suatu wilayah sensitif dan rentan untuk penularan DBD.[10]

\section{Menutup Penampungan Air}

Analisis bivariat menunjukkan adanya asosiasi positif dari kebiasaan menutup wadah air terhadap kejadian DBD, meskipun pada analisis multivariat, variabel ini harus dikeluarkan karena tidak memiliki makna berdasarkan uji statistik (p.>0,05).

Penelitian di wilayah suburban Laos dan Thailand membuktikan bahwa wadah air yang memiliki tutup lebih jarang menjadi tempat jentik nyamuk berkembang biak dibanding kontainer yang tidak bertutup.[8]

Perkembangbiakan nyamuk pada kontiner air merupakan faktor risiko utama wabah DBD di Teluk Dalam pada tahun 2016. Dibuktikan dengan peningkatan risiko kejadian DBD sebesar 3,7 kali lipat berdasarkan analisis multivariat.[10]

\section{Mengelola Barang Tidak Dipakai}

Pengumpulan data penelitian ini menemukan bahwa sebagian responden sudah mengelola barang tidak dipakai yang ada di rumah mereka dengan mengumpulkannya pada pengumpul sampah atau menggunakan kembali barangbarang tersebut dengan fungsi yang berbeda. Berdasarkan hasil analisis, kegiatan tersebut memiliki pengaruh dengan kejadian DBD di lokasi penelitian. Sesuai dengan hasil tersebut, sebuah studi menemukan bahwa menyingkirkan barang bekas memiliki pengaruh terhadap kejadian DBD, dengan risiko 4,24 kali lebih besar bagi yang tidak mempraktikkannya.[6]

Pengelolaan sampah atau barang yang sudah tidak dipakai dapat mengurangi populasi nyamuk. Barang-barang bekas, seperti botol, kaleng, ban, atau plastik dapat menampung air hujan dan menjadi tempat perindukan (breeding place) nyamuk, sedangkan pakaian yang sudah tidak dipakai dapat menjadi tempat beristirahat (resting place) bagi nyamuk.[11]

Mengubur benda yang sudah tidak dipakai tidak disarankan karena dapat menimbulkan kontaminasi lingkungan. Mikroplastik ditemukan pada air leachate yang bersumber dari 
fragmentasi sampah plastik yang terkubur di tempat pembuangan akhir sampah dengan tipe polimer paling dominan yaitu polyethylene dan polypropylene.[12] Jika mengontaminasi air tanah dan dikonsumsi oleh manusia dan hewan, atau diserap tanaman, mikroplastik dapat menimbulkan berbagai macam gangguan kesehatan.

Kemasan produk yang mengandung berbagai jenis bahan berbahaya, terutama logam berat, juga dapat mencemari tanah. Oleh karena itu, direkomendasikan untuk mengelola sampah melalui metode reduce, reuse, dan recycle (3R). Metode ini selain dapat mencegah sampah menjadi tempat perkembangbiakan vektor nyamuk, juga aman bagi lingkungan.

\section{Memelihara Ikan Pemakan Jentik}

Studi ini memperoleh hasil bahwa terdapat pengaruh praktik memelihara ikan pemakan jentik terhadap kejadian DBD. Sebagian besar responden memelihara ikan cupang pada kontainer penampungan air di kamar mandi. Praktik ini dapat membantu mengendalikan populasi nyamuk, dibuktikan oleh sebuah uji eksperimental yang membuktikan bahwa tidak ada jentik nyamuk pada wadah air yang ditempatkan ikan cupang di dalamnya.[13]

Predator larva yang dapat digunakan untuk pengendalian jentik Aedes tidak banyak jenisnya. Ikan pemakan jentik merupakan ikan yang sangat mudah ditemui, murah dan dikembangkan masyarakat. Beberapa jenis ikan ini berkembang biak secara alami dan memakan jentik, seperti ikan cupang, ikan kepala timah, dan ikan cetul. Betta splendens (ikan cupang) merupakan predator alami larva Aedes aegypti.[13]

Selain ikan cupang, ikan cere (Gambusia affinis) dan ikan guppy (Poecilia reticulate) juga merupakan ikan pemakan jentik Aedes. Ikan cere dapat mengonsumsi 100 - 300 larva per hari, sedangkan ikan guppy dapat memakan $80-100$ jentik nyamuk per hari.[14]

Sebuah studi mengamati jumlah larva nyamuk yang dimangsa ikan cupang dan ikan cere selama 6 jam observasi. Setelah 6 kali pengulangan diperoleh rata-rata jumlah larva Aedes aegypti yang dimakan ikan cupang (83,3 ekor), lebih banyak dari ikan cere (63 ekor).[15]

\section{Menggunakan Penghalau Nyamuk}

Sejalan dengan hasil uji statistik studi ini, penelitian Ishak et al. memperoleh hasil bahwa terdapat hubungan antara penggunaan repellent atau penghalau nyamuk terhadap kejadian DBD dengan risiko lebih besar 7,2 kali pada responden yang tidak mempraktikkannya.[16] Penghalau nyamuk memiliki berbagai jenis dan metode penggunaannya, seperti lotion yang memberikan perlindungan langsung pada kulit dari gigitan nyamuk, serta anti nyamuk yang dibakar, berbentuk aerosol, atau elektrik. Beberapa observasi yang dilakukan membuktikan pengaruh berbagai jenis penghalau nyamuk tersebut dengan kejadian DBD.

Sebuah studi menemukan bahwa penggunaan anti nyamuk berkorelasi terhadap kejadian DBD berdasarkan analisis multivariat dengan nilai $O R$ 
$=$ 2,76.[7] Penelitian lain memperoleh hasil bahwa kejadian DBD berisiko 4,2 kali lebih tinggi terjadi pada responden yang tidak memiliki kebiasaan memakai lotion sebagai repellent.[6] Sedangkan responden yang tidak menggunakan insektisida berbentuk aerosol 2 kali lebih berisiko untuk menderita DBD.[17]

\section{Menanam Tanaman Pengusir Nyamuk}

Beberapa jenis tanaman mengandung substansi yang tidak disukai oleh nyamuk. Sebagian mempunyai nilai ekonomis sehingga dapat membantu meningkatkan pendapatan keluarga, salah satu contohnya serai wangi (Cymbopogon nardus).[18] Tanaman pengusir nyamuk seperti serai wangi sering kali tidak ditanam di dalam rumah. Sehingga ada kemungkinan nyamuk tetap betah ada di dalam rumah. Kondisi ini yang mungkin menyebabkan variabel ini, walaupun sebagian responden sudah menanam tanaman Zodia dan serai, tidak memiliki hubungan yang bermakna terhadap penyakit DBD. Hasil serupa dibuktikan oleh Novrita dkk yang membuktikan tidak adanya pengaruh tanaman pengusir nyamuk dengan kejadian DBD. [5]

Beberapa studi menemukan efektivitas lebih tinggi dari tanaman-tanaman dengan kandungan bahan yang tidak disukai nyamuk jika diolah terlebih dahulu. Sari dari tanaman-tanaman tersebut dimanfaatkan sebagai repellent untuk menghindari gigitan nyamuk.

Daun serai wangi (Cymbopogon winterianus Jowitt) memiliki kandungan geraniol, sitronelol dan sitronelal yang bermanfaat untuk menghalau nyamuk. Daun tanaman ini dapat diolah menjadi serbuk serta dikembangkan dalam bentuk sediaan briket. Briket serai wangi dengan konsentrasi 30\% terbukti efektif dalam menghalau nyamuk Aedes aegypti. Berdasarkan hasil pengamatan, nyamuk Aedes sudah mulai menghindar pada menit ke-3 setelah briket dibakar. Semakin besar konsentrasi bahan aktif yang terkandung dalam repellent maka efeknya dalam mengusir nyamuk juga akan meningkat dan daya efektifitasnya juga semakin lama.[19] Daun Citrus aurantifolia (jeruk nipis), kulit Citrus grandis (jeruk bali), dan rimpang Alpinia galanga (lengkuas) merupakan tanaman yang dapat dimanfaatkan sebagai repellent untuk menghindari gigitan nyamuk. Di antara ketiganya, A. galanga yang dapat bertahan selama 4 jam setelah pemakaian dan memberikan perlindungan paling baik.[20]

\section{Menaburkan Larvasida}

Penelitian ini tidak membuktikan adanya hubungan yang bermakna antara menaburkan larvasida dengan kejadian DBD. Hal tersebut kemungkinan disebabkan karena sebagian besar responden sudah secara rutin menguras bak mandi seminggu sekali, sehingga kalau pun nyamuk meletakkan telurnya di kontainerkontainer air, siklus pertumbuhan nyamuk dari telur sampai menjadi jentik belum sempat berlangsung. Selain itu, larvasida yang ditaburkan juga akan ikut terbuang saat menguras wadah penampungan air.

Mendukung hasil studi ini, beberapa studi menemukan bahwa kegiatan menaburkan larvasida di wadah penampungan air juga tidak 
memiliki kaitan dengan keberadaan jentik nyamuk di wadah penampungan air.[8] Salah satu metode pemberantasan sarang nyamuk secara kimiawi adalah dengan menggunakan bubuk abate. Menaburkan 1sdm bubuk abate pada $100 \mathrm{~L}$ air di kontainer air dapat memberikan proteksi selama kurun waktu 2-3 bulan. Namun, pemanfaatan abate harus dengan takaran yang tepat dengan interval waktu tertentu. Ketidakteraturan dan ketidaktepatan dalam pemakaiannya dapat mengakibatkan tidak efektifnya intervensi ini, bahkan dapat menimbulkan resistensi. [21]

\section{Menggunakan Kelambu}

Kegiatan PSN lain yang tidak bermakna secara statistik dalam studi ini adalah penggunaan kelambu. Jumlah pengguna kelambu pada kelompok kasus dan kontrol tidak memiliki perbedaan yang signifikan. Sejalan dengan hasil tersebut, penelitian Ayun dkk juga tidak menemukan adanya pengaruh kebiasaan menggunakan kelambu dengan kejadian DBD.[13]

Kelambu lebih sering digunakan ketika tidur pada malam hari.[22] Hal tersebut dikarenakan penggunaan kelambu pada siang hari sering menimbulkan ketidaknyamanan. Padahal, nyamuk Aedes lebih sering menggigit saat pagi dan sore hari (biting behavior). Sehingga, umumnya orang akan lebih memilih untuk menggunakan repellent untuk menghindari gigitan nyamuk pada waktu-waktu tersebut.

Untuk meningkatkan efektifitasnya, terkadang kelambu atau perangkap berinsektisida juga digunakan untuk menghindari gigitan nyamuk. Namun, praktik ini juga tidak memiliki efek untuk menghindari kejadian DBD.[17]

\section{Memasang Kawat Kasa di Ventilasi}

Pemasangan kawat kasa bertujuan untuk menghalangi nyamuk masuk ke dalam rumah, mencegah mereka untuk berkembang biak dan beristirahat di dalam rumah, serta menggingit penghuni rumah. Meskipun demikian, tidak ada hubungan yang signifikan ditunjukkan oleh variabel ini. Hal ini kemungkinan karena praktik pemasangan kawat kasa di ventilasi rumah hampir sama besar pada kedua kelompok, yaitu $72,3 \%$ untuk responden dari kelompok kasus dan $76,6 \%$ pada responden dari kelompok kontrol. Hasil yang sama ditunjukkan oleh penelitian Ishak dkk yang menemukan bahwa penggunaan kawat kasa pada ventilasi rumah tidak memiliki korelasi yang bermakna dengan insiden DBD.[16] Studi lain menyebutkan bahwa kawat kasa disarankan untuk dipasang di setiap lubang ventilasi pada seluruh ruangan. Sehingga, tidak terdapat celah yang menjadi jalur masuk nyamuk ke dalam rumah.[23]

Secara keseluruhan, kegiatan PSN berpengaruh terhadap kejadian DBD. Bahkan, PSN yang dilakukan dengan buruk 5,842 kali lebih berisiko untuk mengakibatkan kejadian DBD dibandingkan dengan yang melaksanakan kegiatan ini dengan benar.[21]

Populasi vektor yang belum dewasa merupakan target untuk program pencegahan dan pengendalian DBD. Umumnya dilakukan dengan 
cara mengurangi atau mengeliminasi lokasi yang berpotensi menjadi tempat perkembangbiakan larva, dengan mengumpulkan wadah yang tidak dipakai atau membuangnya dalam kampanye pembersihan atau pengelolaan lingkungan, menutup wadah penyimpanan air, mengeringkan talang air atau saluran air, atau menggunakan insektisida yang sesuai. Penggunaan ikan dan Crustacea akuatik sebagai agen pengendali biologis untuk memangsa vektor yang belum dewasa juga dapat berpotensi dalam situasi tertentu.[17]

Hambatan utama untuk menurunkan kejadian DBD yaitu tidak optimalnya pelaksanaan program PSN di masyarakat khususnya di tingkat keluarga. Kesuksesan pemutusan rantai penularan DBD bergantung pada kesadaran dan tanggung jawab masyarakat untuk menjaga kebersihan lingkungannya.[24]

Banyak faktor yang berpengaruh terhadap pelaksanaan kegiatan pencegahan DBD. Salah satu faktor penting adalah pengetahuan. Pengetahuan yang baik mengenai DBD, gejala, transmisi dan pencegahannya dapat mengurangi risiko kejadian DBD.[5] [23] [25] [26] [27]

Pelaksanaan upaya pencegahan DBD bergantung pula pada faktor-faktor lain. Pendapatan rumah tangga, faktor pekerjaan, dan keberadaan nyamuk di lingkungan rumah, terbukti memiliki pengaruh terhadap praktik pencegahan DBD.[26] Sebuah studi menunjukkan bahwa orang yang lebih tua (berusia $\geq 40$ tahun) melakukan praktik pencegahan DBD lebih baik dibandingkan dengan yang berusia $<40$ tahun. Sedangkan responden laki-laki menunjukkan perilaku pencegahan yang buruk bila dibandingkan dengan responden perempuan.[28]

\section{KESIMPULAN DAN SARAN}

Kegiatan PSN yang berpengaruh terhadap kejadian DBD adalah menguras wadah penampungan air di kamar mandi secara rutin minimal satu kali per minggu, menutup wadah penampung air, mengelola benda yang sudah tidak dipakai agar tidak menjadi sarang dan tempat perkembangbiakan nyamuk, menggunakan penghalau nyamuk (repellent), dan memelihara ikan pemakan jentik di penampungan air. Menguras bak mandi menjadi variabel dengan pengaruh paling besar dengan kejadian DBD. Sedangkan, menutup tempat penampungan air terbukti signifikan pada uji bivariat, namun tidak termasuk sebagai faktor yang paling berpengaruh karena tidak memiliki hubungan yang bermakna secara statistik pada pemodelan regresi logistik. Mengedukasi masyarakat mengenai manfaat dan prosedur pemberantasan sarang nyamuk yang benar dapat meningkatkan kesadaran dan partisipasi masyarakat dalam pelaksanaan kegiatan PSN. Praktik PSN secara berkesinambungan dan memperoleh dukungan penuh dari masyarakat dapat menjadi faktor pendukung utama keberhasilan program pencegahan dan pengendalian DBD.

\section{DAFTAR PUSTAKA}

[1] Kemenkes RI. Pedoman Demam Berdarah Dengue Indonesia. In Jakarta; 2017.

[2] Direktorat Jenderal Pengendalian Penyakit dan Penyehatan Lingkungan KKR. Buku 
Saku Pengendalian Demam Berdarah Dengue Untuk Pengelola Program DBD Puskesmas. 2013.

[3] WHO. Dengue: Guidelines for Diagnosis, Treatment, Prevention and Control. Geneva, editor. World Health Organization; 2010.

[4] Dinas Kesehatan DKI Jakarta. Surveilans DKI Jakarta. 2020.

[5] Novrita B, Mutahar R, Purnamasari I. Analisis Faktor Risiko Kejadian Demam Berdarah Dengue Di Wilayah Kerja Puskesmas Celikah Kabupaten Ogan Komering llir. J Ilmu Kesehat Masy [Internet]. 2017;8(1):19-27. Available from:

https://www.google.com/url?sa=t\&rct=j\& $q=\& e s r c=s \&$ source $=w e b \& c d=\& c a d=r j a \& u a$ $\mathrm{ct}=8 \&$ ved $=2$ ahUKEwjqil $6 \mathrm{cp} 67 \mathrm{sAhVCX30K \textrm {H }}$ eaRBzcQFjACegQIARAC\&url=http\%3A\%2F \%2Fjikm.unsri.ac.id\%2Findex.php\%2Fjikm \%2Farticle\%2Fdownload\%2F399\%2Fpdf\& usg=AOvVaw29QAdaCsOoTMQSSOqPIVC w

[6] Ayun LL, Pawenang ET. Hubungan antara Faktor Lingkungan Fisik dan Perilaku dengan Kejadian Demam Berdarah Dengue (DBD) Di Wilayah Kerja Puskesmas Sekaran, Kecamatan Gunungpati, Kota Semarang. Public Heal Perspect J [Internet]. 2017;2(1):97-104. Available from:

https://journal.unnes.ac.id/nju/index.php/ phpj/article/viewFile/11002/6680

[7] Sari TW, Putri R. Pemberantasan Sarang
Nyamuk 3M Plus terhadap Kejadian Demam Berdarah Dengue di Puskesmas Payung Sekaki Kota Pekanbaru: Studi Kasus Kontrol. J Epidemiol Kesehat Indones [Internet]. 2019;3(2):55-60. Available from: http://journal.fkm.ui.ac.id/epid/article/vie $w / 1781$

[8] Vannavong N, Seidu R, Stenström T-A, Dada N, Overgaard HJ. Effects of Sociodemographic Characteristics and Household Water Management on Aedes aegypti Production in Suburban and Rural Villages in Laos and Thailand. Parasit Vectors. 2017;10.

[9] Saleh M, Aeni S, Gafur A, Basri S. Hubungan Pemberantasan Sarang Nyamuk (PSN) dengan Keberadaan Jentik Nyamuk Aedes aegypti di Wilayah Kerja Puskesmas Pancana Kab. Barru. Higiene [Internet]. 2018;4(2):93-8. Available from: https://core.ac.uk/download/pdf/234747 865.pdf

[10] Sitepu FY, Nasution H, Supriyadi T, Depari E. Epidemiological and Entomological Investigation of Dengue Fever Outbreak in South Nias District North Sumatera Province Indonesia 2016. Outbreak, Surveillance, Investig Response. 2018;11(3):8-12.

[11] Rosmal F, Rosidah I. Hubungan Faktor Resiko Kesehatan Lingkungan Dalam Pengelolaan Sampah Padat Dengan Kejadian Demam Berdarah Dengue di Kelurahan Hegarsari Kecamatan 
Pataruman Kota Banjar. J Kesehat Komunitas Indones [Internet]. 2019;15(1):23-34. Available from: http://jurnal.unsil.ac.id/index.php/jkki/arti cle/viewFile/986/785

[12] He P, Chen L, Shao L, Zhang H, Lü F. Municipal Solid Waste (MSW) landfill: A source of microplastics? Evidence of Microplastics in Landfill Leachate. Water Res [Internet]. 2019;159:38-45. Available from:

https://www.sciencedirect.com/science/a rticle/abs/pii/S004313541930377X

[13] Harsono S, Nisaa A. Metode Biokontrol Ikan Cupang (Betta splendens) Sebagai Pengendali Vektor Penyakit DBD di Kartasura Kabupaten Sukoharjo. J Manaj Inf dan Adm Kesehat. 2019;2(2):38-43.

[14] Sarwar M. Control of Dengue Carrier Aedes Mosquitoes (Diptera: Culicidae) Larvae by Larvivorous Fishes and Putting It into Practice Within Water Bodies. Int J Prev Med Res [Internet]. 2015;1(4):232-7. Available from: http://www.aiscience.org/journal/ijpmr

[15] Hartati AT, Rusmartini T, Ismawati. Uji Kemampuan Ikan Manfish (Pterophyllum altum), Ikan Cupang (Betta splendens), dan Ikan Cere (Gambusia affinis) Sebagai Predator Larva Aedes aegypti dalam Upaya Penanggulangan DBD. Pros Pendidik Dr Unisba. 2016;2(2).

[16] Ishak H, Aisyah AS, Mallongi A, Astuti RDP. Risk factors and Fogging Effectiveness of Dengue Hemorrhagic Fever Incidence in the Pontap Public Health Center area in Palopo City, Indonesia_. Enferm Clin [Internet]. 2020;30:294-7. Available from: https://www.researchgate.net/publication /342113828_Risk_factors_and_fogging_ef fectiveness_of_dengue_hemorrhagic_feve r_incidence_in_the_Pontap_Public_Health _Center_area_in_Palopo_City_Indonesia

[17] Bowman LR, Donegan S, McCall PJ. Is Dengue Vector Control Deficient in Effectiveness or Evidence?: Systematic Review and Meta-analysis. PLoS Negl Trop Dis [Internet]. 2016;10(3). Available from: https://journals.plos.org/plosntds/article? id=10.1371/journal.pntd.0004551

[18] Farich A, Perdana AA. Efektifitas Penanaman Tanaman Serai Wangi (Cymbopogon nardus) Terhadap Indikator Maya Index DBD di Kabupaten Pringsewu, Lampung. J Dunia Kesmas [Internet]. 2019;8(4). Available from: http://ejurnalmalahayati.ac.id/index.php/ duniakesmas/article/view/190-198/pdf

[19] Erlia D, Darusman F, Darma GCE. Pembuatan Briket Penghalau Nyamuk (Repellent) dari Daun Serai Wangi (Cymbopogon winterianus Jowitt) dan Evaluasinya. Farmasi [Internet]. 2016;2(2). Available from: http://karyailmiah.unisba.ac.id/index.php/ farmasi/article/view/4706

[20] Misni N, Nor ZM, Ahmad R. New Candidates For Plant Based Repellents Against Aedes Aegypti. J Am Mosq Control Assoc [Internet]. 2016;32(2):117-123. 
Available

from:

https://www.researchgate.net/publication /303887327_New_Candidates_for_Plant-

Based_Repellents_Against_Aedes_aegypti

[21] Priesley F, Reza M, Rusjdi SR. Hubungan Perilaku Pemberantasan Sarang Nyamuk dengan Menutup, Menguras dan Mendaur Ulang Plus (PSN M Plus) terhadap Kejadian Demam Berdarah Dengue (DBD) di Kelurahan Andalas. J Kesehat Andalas [Internet]. 2018;7(1):124-30. Available from:

http://jurnal.fk.unand.ac.id/index.php/jka /article/view/790/646

22. Liu J, Tian X, Deng Y, Du Z, Liang T, Hao Y, et al. Risk Factors Associated with Dengue Virus Infection in Guangdong Province: A Community-Based Case-Control Study. Int Environ Res Public Heal [Internet]. 2019;16. Available from: https://www.ncbi.nlm.nih.gov/pmc/article s/PMC6406885/

[23] Husna I, Putri DF, Triwahyuni T, Kencana GB. Analisis Faktor yang Mempengaruhi Kejadian Demam Berdarah Dengue di Wilayah Kerja Puskesmas Way Kandis Bandar Lampung Tahun 2020. J Anal Kesehat [Internet]. 2020;9(1):9-16. Available from: https://www.google.com/url?sa=t\&rct=j\& $\mathrm{q}=\&$ esrc $=\mathrm{s} \&$ source $=$ web\& $\mathrm{cd}=\& \mathrm{cad}=\mathrm{rja} \& u a$ $\mathrm{ct}=8 \& \mathrm{ved}=2 \mathrm{ahUKEwiAt} 8 \mathrm{WG} 17 \mathrm{DsAhUBA3}$ । KHZ1qCXYQFjAKegQIChAC\&url=https\%3A \%2F\%2Fejurnal.poltekkes-

tjk.ac.id\%2Findex.php\%2FJANALISKES\%2F
article\%2Fdownload\%2F2111\%2F1109\&us $\mathrm{g}=A O v V a w 3 J E A p b Z P p s u k T r 9 H H V e B E N$

[24] Ramadhani F, Yudhastuti R, Widati S. Consciousness Stage Implementation of Mosquito Nest Eradication (MNE) of Dengue Hemorrhagic Fever (DHF). Heal Notions [Internet]. 2017;1(3). Available from:

http://heanoti.com/index.php/hn/article/ view/hn1305

[25] Saied KG, Al-Taiar A, Altaire A, Alqadsi A, Alariqi EF, Hassaan M. Knowledge, Attitude and Preventive Practices Regarding Dengue Fever in Rural Areas of Yemen. Int Health [Internet]. 2015;7:4205. Available from: https://academic.oup.com/inthealth/articl e/7/6/420/2458785

[26] Wong LP, Shakir SMM, Atefi N, AbuBakar S. Factors Affecting Dengue Prevention Practices: Nationwide Survey of the Malaysian Public. PLoS One. 2015;

[27] Elsinga J, Schmidt M, Lizarazo EF, VincentiGonzalez MF, Velasco-Salas ZI, Arias L, et al. Knowledge, Attitudes, and Preventive Practices Regarding Dengue in Maracay, Venezuela. Am J Trop Med Hyg. 2018;99(1):195-203.

[28] Rakhmani AN, Limpanont $Y$, Kaewkungwal J, Okanurak K. Factors Associated with Dengue Prevention Behaviour in 
Jurnal Untuk Masyarakat Sehat (JUKMAS)

Lowokwaru, Malang, Indonesia: a Cross-

sectional Study. BMC Public Health

[Internet]. 2018;18. Available from:

https://www.ncbi.nlm.nih.gov/pmc/article s/PMC5948848/pdf/12889_2018_Article_ 5553.pdf 